\title{
Applying advanced methods of evaluation of level of innovative development for industrial sector
}

\author{
Natalia V. Kretova \\ Department of Economic Theory and Finance \\ National Research Irkutsk State Technical University \\ Irkutsk, Russia \\ vip.kretova@inbox.ru
}

\author{
Elena Yu. Tsaregorodtseva \\ Department of Management, Service and Tourism \\ East-Siberian Institute of Economics and Law \\ Irkutsk, Russia \\ elenapopova86@mail.ru
}

\author{
Galina I. Khohlova \\ Department of Economic Theory and Finance \\ National Research Irkutsk State Technical University \\ Irkutsk, Russia \\ hgi08@yandex.r
}

\begin{abstract}
The paper considers modalities for the operation of the industrial sector, analysis of the level of innovative development in industry from the systematic viewpoint. To determine the new step, the radical transformation of industrial policy is needed. To address this issue, the methods of evaluating the innovative development level for the industrial sector are proposed by the authors of the article provided by the description of this methodology. Therefore, the objective of the report is to consider the methodology of development innovation as the efficient growth of industrial policy. The aim of the paper is to consider the issue of evaluating the level of innovative development on the basis of the domestic and international researches. This requires accomplishing the following objectives. 1. To consider the scientific researches in recent researches and publications in the innovative development area. 2. To submit the methods of evaluation of the level of innovative development for industrial sector. 3. To provide recommendations for practical application and further use of methodology of the innovative development administration for industrial sector.
\end{abstract}

Keywords - Innovative development, industry, methods of evaluation, economic development.

\section{INTRODUCTION}

For the current period of development, a considerable amount of works is dedicated to evaluate the level of innovative development of countries and regions. The analysis in that area started recently, and a number of methodological approaches for accomplishing that issue have been used along with it. Nowadays, unified evaluation of formation and development of comprehensive measures at level of innovative development have not been formed yet. This implies continuation of scientific researches in that area. Economic development of evaluation of the level of innovative development provides the structure of development factors in economics and society in general and also social institutions, incentives and restrictions that contributed to such developments in a certain country or region [6].

The industrial economy is accompanied by the growth of physical, mainly private capital, the number of employees and the productivity of their labor. It should be noted that Schumpeter concentrated mainly on labor productivity, and according to Keynes, investments are the most suitable model of economic growth, including government. It is necessary to agree with J. P. Morgon, who believes that money in the industrial model is a means of circulation (commodity-moneycommodity) and investment.

As for the present time, in the message of the Federal Assembly (2014), V.V. Putin explained that the raw-material model of the economy has been exhausted. Acceleration of economic growth rates announced for 2013-2015. The change from $3.6-3.7 \%$ to $5-6 \%$ was a drastic change in business processes in non-primary sectors, small and medium businesses (SMEs), reform of economic legislation, often using accounts of competitors. In his opinion, innovative ideas are needed, in particular the creation of a new methodology for assessing the innovative development of domestic industry [7].

The priority area for development of innovative activities is identification and improvement of the form of its financial incentives.

The ability to perceive and implement innovative development for industrial sector development is the key to survival in acute competition that is an urgent strategic task of the national economy [7]. The potential to solve this problem is focused on the efforts of research and development teams. An innovation form of economy provides a systemic use of scientific achievements in industry. This tool assumes that during the development of new technologies and innovative products, the enterprise is concentrated not only on its internal forces, that is, corporate units that provide knowledgeintensive technologies, but also vigorously attracts ideas and experts from the macro environment. 


\section{LITERATURE REVIEW}

An evaluation innovative development for industrial sector issue is subject of research of many scientists, including works of I. Novikova, I.M. Bortnik, Sechenya G.I., Amosenokova E.P., Bazhanova V.A., Veselaya L.S., Sokolova A.V., Borisova V.N., Pochukaeva O.V., Volkova N.N., Romanyuk E.I. It must be noted that many publications address the methods of evaluation of innovative territory potential by combining some indicators in integrated. Thereby not so much attention is dedicated to the measures of innovative development of industrial sector [4].

According to Russian Federation legislation, «innovative activities in the area of science and technology build on actions aim at establishing and introduction of scientific and technical achievements and new products (goods, services), which are expressed in an objective form, including:

- Experimental development, technological, project, research, licensing, patents, and other work;

- Implementation of technological upgrading and preparation of own production;

- Realization of testing, goods`certification (works, services) »

Therefore, in foreign and national literature, the term "innovation" means simultaneously and process of production and concrete result of this process.

\section{Problem Statement And Research ObJective}

The purpose of this study is to provide a methodology for assessing the level of innovation in industry. The main objective for the transition to an innovative development path lies in effective economic growth and the theory of industrial policy in the post-crisis years (2010-2015), which are studied by fundamental researchers of leading universities and scientific centers around the world (Harvard, Oxford, Cambridge, Princeton, ). Domestic researchers are Abalkina L., Akayev A., Glazyev S., Grinberg R., V. Inozemtseva, Nigmatullina L., Polterovich V., Rybakova F., as well as a number of other economists. At the same time, real policy is based on market fundamentalism with a rigid administrative and power influence on the industrial business. This situation will lead to a further development of the economy [2]. The new political economy is aimed at justifying the content and role of the new methodology for assessing the level of innovation development and the transition from debt capitalism to innovation-social capitalism with changes in industrial policy methods.

The problem of the use of certain methodologies (such as works of Volkova N.N., Romanyuk E.I.) is that not all of the represented for evaluation indicators can be obtained from the available statistic data. Evaluation criteria, suggested in the methodology, are more likely to be obtained through further research and study on materials of financial reporting, which is pretty difficult in connection with financial opportunities.

Low competitiveness of the products that are produced in the Russian industrial complex is attributable to a low level of innovative development. Industrial enterprises, for its part, contribute to establishment of total volume of innovative productions. The level of their innovative development from 2008 to 2015 did not exceed $14 \%$, and the indicator of innovative productions in combination with supplied products reaches $12 \%$. Such indicators pointed to the low-level interest of enterprises of the industrial sector to the innovative technologies. To identify the factors that impede the development of innovative activities in the manufacturing industry, it is necessary to be able to assess the level of its development.

TABLE I. INDICATORS OF THE LEVEL OF DEVELOPMENT OF INNOVATION IN RUSSIA [5]

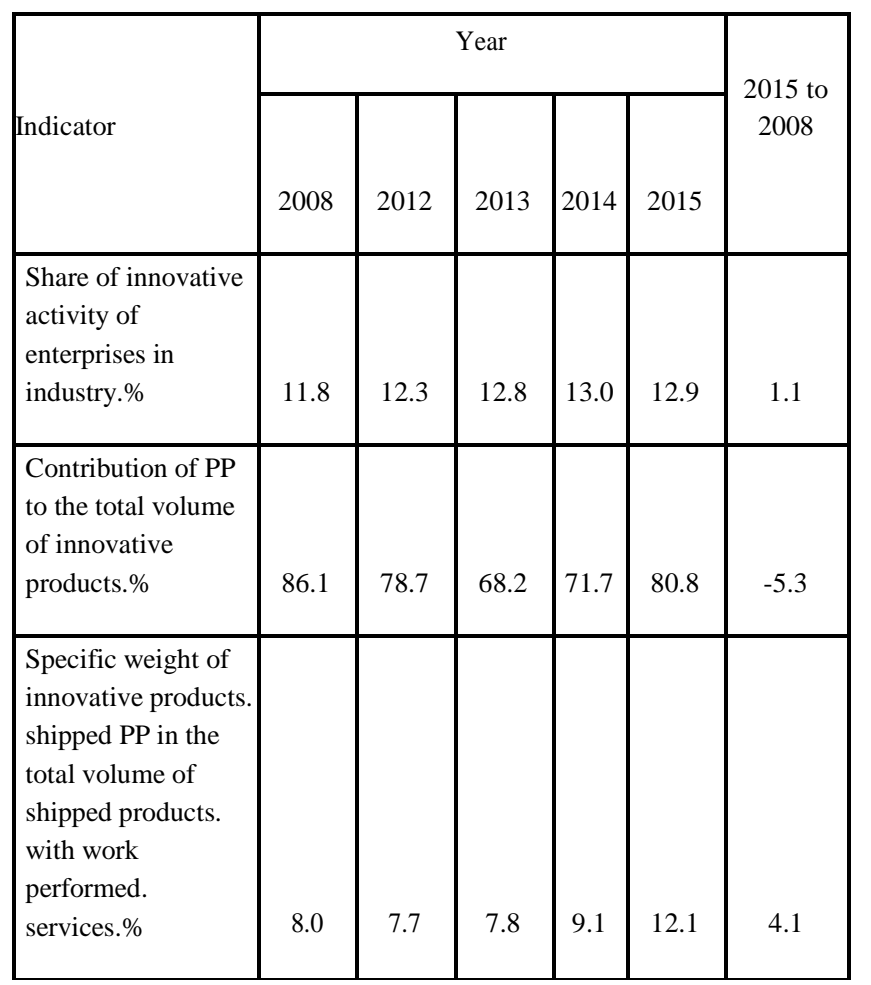

The above-mentioned study of the merits and demerits of methodologies in assessing the level of innovation activity in the economic sector shows that none of the developments can be used to measure the level of innovation development in the industrial sector of the region (Table 2).

TABLE II. THEORIES OF METHODS THAT CHARACTERIZE THE ASSESSMENT OF INNOVATION AND THE ECONOMIC SECTOR

\begin{tabular}{|l|l|l|l|l|l|}
\hline Methodology & $\begin{array}{l}\text { Objectiv } \\
\text { ity and } \\
\text { data } \\
\text { availabil } \\
\text { ity }\end{array}$ & $\begin{array}{l}\text { Simplicit } \\
\text { y of the } \\
\text { calculati } \\
\text { on }\end{array}$ & $\begin{array}{l}\text { Simplicity } \\
\text { of results } \\
\text { analysis }\end{array}$ & $\begin{array}{l}\text { Applicat } \\
\text { ion at } \\
\text { the } \\
\text { regional } \\
\text { level }\end{array}$ & $\begin{array}{l}\text { Application } \\
\text { to the }\end{array}$ \\
$\begin{array}{l}\text { assessment } \\
\text { of the level }\end{array}$ \\
$\begin{array}{l}\text { Factor analysis of } \\
\text { innovative } \\
\text { development at the } \\
\text { regional level } \\
\text { (Novikova I., Bortnik } \\
\text { IM,) }\end{array}$ & + & - & + & + & \\
\hline
\end{tabular}




\begin{tabular}{|l|l|l|l|l|l|}
$\begin{array}{l}\text { The level of regions } \\
\text { according to the } \\
\text { rating of their } \\
\text { innovative activity } \\
\text { (Gusev AB) }\end{array}$ & +- & + & +- & + & - \\
\hline $\begin{array}{l}\text { Evaluation of } \\
\text { innovative } \\
\text { development of } \\
\text { regions (Volkov NN, } \\
\text { Romanyuk RI) }\end{array}$ & +- & + & +- & + & - \\
\hline $\begin{array}{l}\text { Methods for } \\
\text { estimating the levels } \\
\text { of development of } \\
\text { innovative potential } \\
\text { in the machine- } \\
\text { building industry (VN } \\
\text { Borisov, OV } \\
\text { Pochukaeva) }\end{array}$ & + & + & - & + & +- \\
\hline $\begin{array}{l}\text { Indicators of } \\
\text { scientific and } \\
\text { technical capabilities } \\
\text { of the region (V. } \\
\text { Polterovich, F. } \\
\text { Rybakov) }\end{array}$ & + & + & + & + & \\
\hline
\end{tabular}

In the presented technique, Borisov VN, PochukaevaO.V. proposed applying an assessment of the level of development of innovation development in industries using the connections of two indicators: the share of products of innovative companies and innovative products in the total volume of production. In turn, the application of the assessment on the available indicators does not take into account the level of involvement of enterprises in the industrial sector in innovation and labor productivity in the direction of producing innovative products, which, in the opinion of the authors, is very important for evaluating the results of innovation in all industries.

At the same time, it is necessary and topical to develop a methodology for assessing the level of development of innovation in the industrial sector by applying these state statistics, which does not require additional study, as well as using methods for compiling regional ratings at the levels of their innovative development in the industrial sector.

\section{METHODOLOGY DESCRIPTION}

According to the objectives, authors suggest the methods of evaluating the level of innovative development for industrial sector, which consists of the three preparatory phases. To evaluate the level of innovative development in industry, it is needed to provide such indicators as: 1. Defining parameters for calculation the levels of innovative developments. 2. Identification of adjusted rates for every unit of observation.3. Identification of integral indicator that characterizes the level of innovative development in industry for the unit of observation [1].
TABLE III. METHODS OF EVALUATION OF THE LEVEL OF INNOVATIVE DEVELOPMENT FOR INDUSTRIAL SECTOR

\begin{tabular}{|l|l|}
\hline Name of phase & Sighs \\
\hline $\begin{array}{l}\text { 1. Defining parameters } \\
\text { for calculation the levels } \\
\text { of innovative } \\
\text { developments (ID) }\end{array}$ & $\begin{array}{l}\text { Defining the number of statistic data, that } \\
\text { characterizes the level of innovative } \\
\text { development for enterprises in industrial } \\
\text { sector. }\end{array}$ \\
\hline $\begin{array}{l}\text { 2. Identification of } \\
\text { adjusted rates for every } \\
\text { unit of observation }\end{array}$ & $\begin{array}{l}\text { During the calculation of adjusted rates the } \\
\text { maximum or minimum value of every } \\
\text { parameters taken into account, keeping in } \\
\text { mind was a parameter forward or backward. } \\
\text { IDi =xi - min (xi)/ } \Delta \text { (xi) } \\
\text { or IDi }-\Delta \text { (xi)/ max (xi)- xi, } \\
\text { (keeping in mind the original indicator), } \\
\text { where xi is the original value of indicators } \\
\text { for the territory. }\end{array}$ \\
\hline $\begin{array}{l}\text { 3. Identification of } \\
\text { integral indicator that } \\
\text { characterizes the level of } \\
\text { innovative development } \\
\text { in industry for the unit of } \\
\text { observation }\end{array}$ & $\begin{array}{l}\text { The integral indicator calculates: } \\
\text { ID is the adjusted data in I territory, } \mathrm{n}-\text { the } \\
\text { number of indicators, that is taken into } \\
\text { account while calculating }\end{array}$ \\
\hline
\end{tabular}

Presented indicators allow identification of scope of the productive forces in production of innovative products to calculate comprehensively the result of their innovative development and implement the analytic comparison with the industry results.

In addition to the methods of evaluation of the level of innovative development for industrial sector in foreign practice, there is wide application of instruments for financial incentives of innovative activity for industrial sector, which are presented in Table 3.

TABLE IV. MAIN INSTRUMENTS OF FINANCIAL INCENTIVES FOR RESEARCH AND DEVELOPMENT FOR INDUSTRIAL SECTOR

\begin{tabular}{|c|c|}
\hline $\begin{array}{c}\text { Instruments of financial } \\
\text { instruments }\end{array}$ & Countries \\
\hline Tax research credit & $\begin{array}{c}\text { USA, Japan, Mexico, South Korea, } \\
\text { Italy, Canada, Norway, France, Spain, } \\
\text { Portuguese }\end{array}$ \\
\hline $\begin{array}{c}\text { Additional tax deductions } \\
\text { for income tax } \\
\text { Australia, Austria, Hungary }\end{array}$ \\
\hline $\begin{array}{c}\text { Special preferential terms for } \\
\text { core funding write-off }\end{array}$ & $\begin{array}{c}\text { Ireland, Great Britain, France, } \\
\text { Germany }\end{array}$ \\
\hline $\begin{array}{c}\text { Investment tax credit } \\
\text { Reduced rates for VAT for } \\
\text { products of innovative means } \\
\begin{array}{c}\text { Special tax incentives for small } \\
\text { enterprises in NIOCR sphere }\end{array}\end{array}$ & $\begin{array}{c}\text { Germany, Great Britain, Sweden, } \\
\text { Italy } \\
\text { Canada, Korea, Norway, Japan }\end{array}$ \\
\hline
\end{tabular}

In foreign practice, there are two main models for formation of tax breaks. The first model implies use of discount in the volume of incurred costs for innovate, when from the taxable income is subtracted in the amount which exceeds the cost of research and development (Australia, Singapore). The second model is based on use of tax breaks' 
incremental mechanism with the maximum ascertainable value (Taiwan, France).

For example, in France, the tax credits for research and development reached the highest value (to 50 per cent). In some countries, the legislation provides for use of both models at the same time, but only for different taxpayers and economic costs. In particular, in the US incremental tax credit on basic research of commercial enterprises can be complemented with volume benefit. It is a common practice to limit for taxation's reductions taking into account the costs of research and development. Therefore, Japan and the Republic of Korea tax breaks shall not exceed 10 per cent of corporate tax`s amount, in Canada - 75 per cent, on Taiwan - 50 per cent.

In this way, types and mechanisms of using fiscal stimulus instruments (the procedure for granting tax credit, tax research loan, standards and time frame for core funds' depreciation, VAT for innovative products) vary in different countries. However, general criterion for use is level of innovative activity of companies and a result of the introduction of research and development.

With regard to development of taxation stimulation of the small and medium innovative entrepreneurship work, than it consists in legislation adjustment and simplification procedure of administration of taxes and fees, notably:

In development of mechanisms of customs regulation, regarding Russian innovative enterprises;

- In improsing differentiated scale of insurance premiums tariff on entities of small and medium entrepreneuship, applying special fiscal regimes. At the same time level of insurance premiums tariff be useful to establish according to profile of main activity of taxpayer and to its valuation of fiscal regime.

- For example, could be decresed the level of total tariff for entities of small and medium entrepreneuship, involved in introduction of scientific and technical activity [4].

\section{CONCLUSIONS И DIRECTIONS FOR FURTHER INVESTIGATION}

Through the provided methods for increasing the level of the innovation development in industrial sector from the practical point of view, it is needed to realize following activities: providing tax relief and subsidy of interest rates on loans for enterprises in industrial sector, that perform the innovative development; implementation of a system of a preferential taxation for enterprises that have been investing in perspective scientific research; significant increase of the wage of staff that is working in scientific and industrial area; stronger regulation of prices and tariffs for the goods of natural monopoly that are the suppliers of raw material for enterprises in all sectors of industry; realization of the range of measures, aimed at creating a regional order in order to reorient the industrial complex from the imported goods to the Russian; to assist the enterprises in industrial sector in realization of their development.

The government took steps to solve the accumulated problems in the renewal's area of fixed assets in particular through the increase of the limits of state capital investment within Federal address investment programme and national programme for priority areas` development of economy which have important social meaning. For example, to enhance the Russian manufacturing and industrial capacity, a special focus was placed on productive development of aerospace engineering, nanotechnology, composite materials, atomic and hydrogen power engineering, biomedical life support technologies and protection of humans and animals, certain areas of environmental management and ecology.

An important focus of providing incentives to industrial companies that explore new products; in foreign practice there are methods of financial incentives.

TABLE V. FINANCIAL METHODS OF INCREASING THE LEVEL OF THE INNOVATION DEVELOPMENT IN INDUSTRIAL SECTOR IN DIFFERENT STATES

\begin{tabular}{|c|c|}
\hline Method & Using countries \\
\hline \begin{tabular}{l}
\multicolumn{1}{c}{ Right of governmental research } \\
facilities to be participants (shareholders, \\
founders) in commercial innovative \\
companies
\end{tabular} & $\begin{array}{l}\text { Denmark, Spain, Norway, } \\
\text { France, Sweden }\end{array}$ \\
\hline $\begin{array}{l}\text { Stimulation of establishment of } \\
\text { collaborative enterprises by science } \\
\text { institutes and business structures }\end{array}$ & $\begin{array}{l}\text { Great Britain, Germany, } \\
\text { Denmark, Ireland, PRC, USA, } \\
\text { France, Sweden }\end{array}$ \\
\hline $\begin{array}{l}\text { Direct financing of innovative } \\
\text { enterprises ( grants, soft loans, other } \\
\text { programs of financing) }\end{array}$ & $\begin{array}{l}\text { Great } \text { Britain, Germany, } \\
\text { Denmark, EU, India, PRC, } \\
\text { Norway, USA, France, } \\
\text { Sweden }\end{array}$ \\
\hline $\begin{array}{l}\text { Financial support of venture capital } \\
\text { enterprises in innovative spheres }\end{array}$ & $\begin{array}{l}\text { Germany, Greece, EU, } \\
\text { India, Norway, Sweden }\end{array}$ \\
\hline $\begin{array}{l}\text { Support of authors and developers } \\
\text { through additional payment for employees } \\
\text { when commercial using of their inventions }\end{array}$ & \begin{tabular}{llr}
\multicolumn{1}{c}{ Great } & Britain, & Greece, \\
Denmark, & PRC, & Norway, \\
France & &
\end{tabular} \\
\hline $\begin{array}{l}\text { Permission for civil servants - } \\
\text { employees of research facilities to } \\
\text { participate in commercial activity for } \\
\text { implementation scientific researches } \\
\text { (work in multiple jobs, hold shares, } \\
\text { participate in company management) }\end{array}$ & $\begin{array}{l}\text { Great Britain, Greece, } \\
\text { Denmark, PRC, France }\end{array}$ \\
\hline
\end{tabular}

There are two opportunities to stimulate research and development in different countries: directly (funding from the budget) and indirectly (tax policies). The system of benefits for companies, leading in research and development, share some common features in all countries, in particular, focused on payment of single sum in the State budget - profit tax that suffers from all sorts of deduction. Implemented in numerous countries, profit tax can be based on total cost of companies research and development or on the increase in expenditures for research and development for several years (Austria, Hungary, Britain, Denmark and Czech Republic).

Special preferential terms for write-off of core funds work in Ireland, Britain, France, and Germany. Innovative enterprises are entitled to write-off recurrent expenditure for research and development fully during the reporting period in which they were made. In some countries, it is possible to postpone losses on other tax periods (France and Germany) [8]. 
Study allows authors to make such general conclusions and synthesis relating to applying advanced methods of evaluation of the level of innovative development for industrial sector:

1. The problem of assessing the innovation activity of the industrial sector and considering the scientific approaches of the latest research and publications in the field of innovation development

2. In order to identify the factors that impede the development of innovative activity in the manufacturing industry, it is necessary to be able to assess the level of its development, so the article presented the indicators of the level of development of innovation in Russia

3. In accordance with the set tasks, the authors proposed a methodology for assessing the level of development of innovation in the industrial sector, which consists of three consecutive stages.

The proposed methodology makes it possible to assess the level of development of innovation in the industrial sector, as well as labor productivity in the production of innovative products, taking into account the volume of output, the degree of involvement of enterprises in the industrial sector of the economy.

\section{References}

[1] A.S. Nechaev, O.V. Antipina., A.V. Prokopyeva, Life Science Journal, № 11 (11), pp. 574-575. China 2014.

[2] A.S. Nechaev, O.V. Antipina, Technique of tax rates and customs duties updating as the tool of enterprises innovative activity stimulation, Modern Applied Science, № 9 (2), pp. 88-96. Canada 2015.

[3] A.V. Prokopyeva, A.S. Nechaev, Key features of risks of company innovative activities, Middle East Journal of Scientific Research, № 17 (2), 2013, pp. 233-236.

[4] E. Yu. Popova, World Applied Sciences Journal 27, pp. 260-265, December 2013.

[5] G. Khokhlova, D. Okladnikova Middle-East Journal of Scientific Research, №12. pp. 36-41, 2014.

[6] K. R. Bibarsov., N.V. Kretova. E. Yu. Popova ERSJ - European Research Studies Journal, pp. 98-110, Greece 2017.

[7] O. Muftahova, A. Nechaev, O. Antipina, International Journal of Economics and Financial Issues, № 5 (4), pp. 1060-1065, Turkey2015.

S. Emmanuel, Technological Forecasting and Social Change, vol. 119, pp. 1-17, 2015. 